\title{
The Erber: Tracing Global Trade through a London Building
}

\section{Sarah Ann Milne}

In 1617, the writer and traveller Fynes Moryson marvelled that London's mercantile elite were 'stately for building, yet [their houses] being built all inward, that the whole room towards the street may be reserved for the shops of tradesmen, [they] make no show outwardly, so as in truth all magnificence of London is hidden from strangers at the first sight. ${ }^{1}$ Moryson described in this passage the model of a London courtyard house, a centuries-old construction that was only effectively abandoned in the rebuilding after the Great Fire of $1666 .{ }^{2}$ Long before the Fire however, in 1603, John Stow was already lamenting the loss of London's elite courtyard houses which were commonly becoming sub-divided and converted into tenements to accommodate a growing number of diverse citizens and their commercial ventures. ${ }^{3}$ Between 1550 and 1666, the density of people per acre in London doubled from 100 to 200, and even conservative estimates of the rising population within the walls attest to the rapid change affecting city space as internal migration from England's counties soared. ${ }^{4}$ At the same time, global goods poured into and out of London's port at a rate never seen before, leading Edmund Howes' to declare that London was 'the choicest storehouse in the world' in 1611.5 Rather than descend into chaos or decline, London's built environment remarkably absorbed the influx of people and trading goods during this period of unsettling change, enabling

\footnotetext{
${ }^{1}$ Fynes Moryson quoted in I. Archer, 'Material Londoners?', in L. Orlin (ed.), Material London ca. 1600 (Philadelphia, 2000), 174-192, 182.

${ }^{2}$ Excepting the continuation of this type for institutional uses, for example by London's livery companies.

${ }^{3}$ J. Stow, 'The Suburbs without the walls', in C.L. Kingsford (ed.), A Survey of London. Reprinted from the Text of 1603 (Oxford, 1908), 69-91; 'Bridge warde without [including Southwark]', in C.L. Kingsford (ed.), A Survey of London. Reprinted from the Text of 1603, (Oxford, 1908), 52-69.

${ }^{4}$ V. Harding, 'City, capital and metropolis: the changing shape of seventeenth-century London', in J.F. Merritt (ed.), Imagining Early Modern London: Perceptions and Portrayals of the City from Stow to Strype, 1598-1720 (Cambridge, 2001), 117-143, 124.

${ }^{5}$ E. Howes, The Abridgement of the English Chronicles...vnto the end of the yeare 1610 (London, 1611); R. Davis, English Overseas Trade, 1500-1700 (Basingstoke, 1973); Dietz's economic study of overseas trade showed that between 1561-7 and 1607-13 imports entering the city more than tripled: B. Dietz, 'Overseas trade and metropolitan growth', in A.L. Bier and R. Finlay (eds.), London 1500-1700: The Making of a Metropolis (London, 1986), 115-140.
} 
increasingly ambitious global enterprise to remain grounded in densely occupied local spaces.

Historians have frequently argued that London's livery companies (guilds) were a stabilising force in the city, providing important institutional structures for the ordering of society whilst supporting considerable social mobility for newcomers to the city. ${ }^{6}$ The livery companies' role as administrators of many of London's buildings is less well considered, yet it can be argued that the acquisition and management of corporate properties was one of the means through which this stability and economic growth was achieved. Ranked third in order of precedence on account of its importance and wealth, the Drapers' Company was one of the foremost London livery companies. It assumed responsibility for maintaining standards in London's trade of drapery (the production and exchange of woolen cloth). However, during the sixteenth century the Drapers lost much of their regulatory power, and by the early seventeenth century the Company's membership was drawn from a far wider range of trades. In particular, the Company oligarchy came to be composed of merchants with interests in the trade of all sorts of goods with well-established European ports. Moreover, as leaders of newly incorporated trading companies, these merchants increasingly held stakes in commercial exchanges across an expanded territory. Though the 'globality' of the sixteenth and seventeenth centuries' was not as comprehensive as in later centuries, new long-distance trading relationships established in these centuries with Africa, Asia, the Levant, the Americas, and Russia proved transformative and enduring. ${ }^{7}$ At the same time, by the middle of the sixteenth century, the city companies' position as regulators of London trade and craft was weakened. However, the companies were deeply embedded in the city's social, political and spatial organisation, and, notably, their role as significant landlords was established long before their commercial influence began to decline. This paper is concerned with the ways in which the most prestigious livery companies maintained a spatial infrastructure that supported the mercantile interests of its members and, in turn,

\footnotetext{
${ }^{6}$ I. Archer, The Pursuit of Stability: Social Relations in Elizabethan London, paperback edn. (Cambridge, 2002); J.P. Ward, Metropolitan Communities: Trade Guilds, Identity and Change in Early Modern London (Stanford, 1997); Rappaport, Worlds within Worlds, 78; G.D. Ramsey, 'The recruitment and fortunes of some London freemen in the mid-sixteenth century', in The Economic History Review, 31 (1978), 526-40.

${ }^{7}$ W. Pettigrew, 'Corporate Constitutionalism and the Dialogue between the Global and the Local in Seventeenth Century English History' in Itinerario, 39:3 (2015), 487-501.
} 
contributed to the continuing relevance of the companies in city life. Through a case study of one significant courtyard house owned by the Drapers' Company and known as 'The Erber', this paper argues that mercantile livery companies supported London's growing centrality within an expanding network of trade through the use and development of corporate properties.

The Erber was almost certainly developed as an aristocratic city residence in the fourteenth century and held by courtly elites until it was purchased by the Worshipful Company of Drapers in 1541. The property was situated in an area especially densely inhabited in the sixteenth century, convenient both to the Thames and to the city markets of Cheapside and the Stocks (see fig. 1). ${ }^{8}$ Despite the pressure exerted on this area of London as it filled up with goods and people, the Erber was retained as one property, arranged around a number of open courtyards, until its destruction in 1666. Following the normal pattern of such urban courtyard houses, it was formed of one principal house, which was surrounded by a range of smaller houses. Located on the east side of the busy thoroughfare of Dowgate Hill in the City of London, the Erber's main residence was hidden behind service accommodation; the gateway into a small paved courtyard was marked by two ornately-carved posts which projected into the street outside. These posts marked out the homes of the city's Sheriffs and Lord Mayors. ${ }^{9}$ Buried behind the roadside gatehouses and beyond the entrance courtyard, the Erber's great hall rose up to the west, probably on a vaulted undercroft used as a basement warehouse. The high-status ground-floor hall divided the front courtyard from a far larger rear yard suitable for receiving goods delivered via a back entrance on Bush Lane. To the north, this utilitarian rear yard was connected to another long commercial yard, and to the east lay an enclosed garden and 'herber' of a very special quality, likely inferred in the building's name. ${ }^{10}$ Long galleries at first floor level ringed both the backyard and garden, while shop/house tenements filled the west elevation, insulating the quiet garden from Bush Lane.

\footnotetext{
${ }^{8}$ Harding, 'City, capital and metropolis', 124.

9 J.A. Repton, 'On the Posts anciently placed on each side of the Gates of Chief Magistrates of Cities in England' in Archaeologia 19 (1821), 383-385.

${ }^{10}$ DCA, RA 1580-81, f.13v-14r; RA 1588-89, f.14v-15r; For discussion of urban gardens see: P. Henderson, The Tudor House and Garden: Architecture and Landscape in Sixteenth and Early Seventeenth Centuries (London, 2005)
} 
Approximately thirty to forty people, ranging from elite merchants and their families, factors, servants, slaves, tradesmen, and craftsmen, might have occupied the Erber at any one time.

Records relating to the building suggest that the Drapers' Company recognised the value of this high-status property, having proactively set out to acquire and preserve it. The Drapers' decisions taken in relation to the Erber illuminate the ways in which London's wealthiest livery companies could work against densification and overdevelopment of the City's built environment. An important motivation in the companies' resistance to subdivision and the building-over of open spaces was the provision of city-centre housing for elite merchants with developing links to global trade.

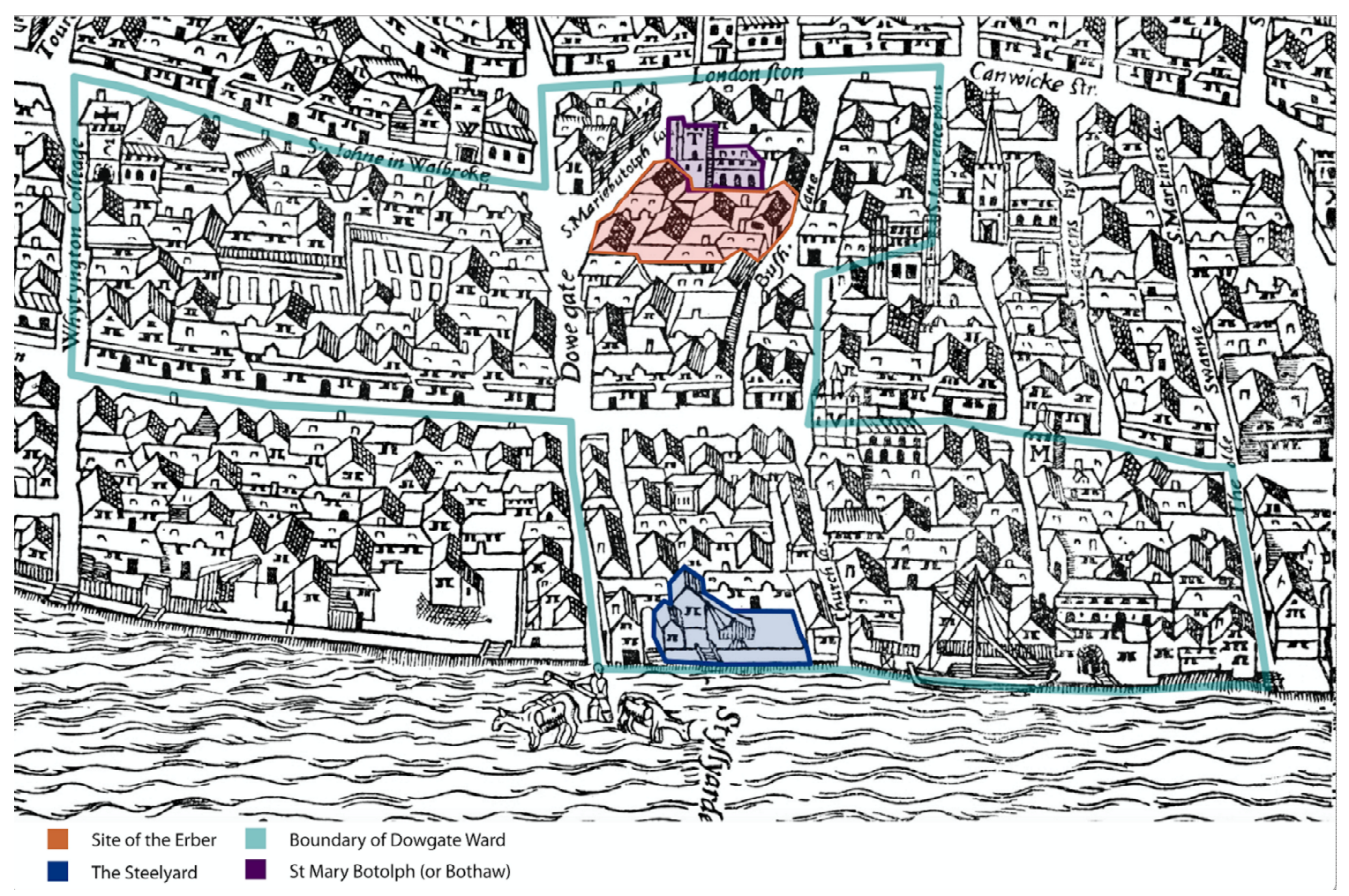

Fig. 1. Civitas Londinvm, the Agas map (c.1562). Adapted from http://mapoflondon.uvic.ca/map.htm, accessed 3 Sep 2017.

By 1640, entry into the ranks of London's mercantile elite was increasingly restricted, and the wealth of this group was also more highly concentrated than before. In his seminal book, Merchants and Revolution, Brenner described how the 
engagement of London's mercantile elite in the new overseas trading companies was key to their appearance as a 'cohesive and dominant socio-political group' in early seventeenth-century England. ${ }^{11}$ As mercantile success was ever-more dependent on participation in maritime trading companies, involvement in the governance of livery companies waned, with service in the guilds appearing burdensome and unnecessary. Urban governance too was reliant on the service of the same men, for livery company membership was foundational to London's political structure, with city leaders drawn from the ranks of the companies. ${ }^{12}$ Service in corporate and civic offices entailed significant financial and time investments, leading many merchants to avoid or decline positions of responsibility. Even so, a study of 140 Jacobean Aldermen, demonstrating that theirs was 'a prodigious wealth by the standards of the day...placing them on a par with major landowners,' reinforces the link between financial prosperity and civic office and underscores that many men did continue to accept positions of authority in the city, even though there was an ever-smaller pool of suitably wealthy candidates. ${ }^{13}$

Holding the office of Alderman, Sheriff, or Lord Mayor was still seen as a marker of success, as was service as Master, Warden or Assistant in an important livery company. Further, in comparison to the new trading companies, the livery companies were asset rich, an important point to note, for, despite their wealth, civic service did not inspire wealthy mercantile men to invest in urban housing. In striking contrast to the elites of other European cities, merchants tended to plough back individual profits, often wrought through global adventures, into business or into the acquisition of country estates. ${ }^{14}$ If men suitable for office were to stay rooted in London and active in its systems of governance, where were they to live? Livery companies appear to have compensated for many merchants' reticence to invest in local property; the companies perhaps even actively enabled the choice of the mercantile elite to divert the spoils of their commercial success elsewhere. Analysis of corporate property management suggests that the livery

\footnotetext{
${ }^{11}$ R. Brenner, Merchants and Revolution: Commercial Change, Political Conflict and London's Overseas Traders (Cambridge, 1993), 83.

${ }^{12}$ R. Grassby, The Business Community of Seventeenth-Century England (Cambridge, 1995), 229.

${ }^{13}$ K. Wrightson, Earthly Necessities: Economic Lives in Early Modern Britain (New Haven, 2000), 191

${ }^{14}$ For comparison see: R.A. Goldthwaite, 'The Florentine palace as domestic architecture', The American Historical Review, 77 (1972), 977-1012; R.J. Goy, Building Renaissance Venice: Patrons, Architects and Builders, c.145-1500 (New Haven and London, 2006).
} 
companies recognised the advantages of retaining appropriately reputable city houses, well located in relation to the transportation of goods and with large halls for the dispensation of honourable acts of hospitality critical to those holding civic office. ${ }^{15}$ Though courtyard houses were broadly under threat, houses of this sort were essential if the mercantile elite were to continue to engage in civic and livery company governance rather than disengage completely in favour of their trading activities or retreat to the country. Company properties like the Erber grounded elite merchants in the city built environment, enabling them to live close to the centre of commercial, political and civic activity. The retention and preservation of buildings like the Erber served to bind the city, through its livery companies, to the political, social and economic dynamics of global mercantilism.

At the same time, the micro-history at the heart of this paper reveals that the 'everyday' built environment of sixteenth and seventeenth century London was shaped not just by the city elite. Also relevant to that process were the different sorts of tenants of the Drapers' Company, who benefited from the expansion at all levels of London's mercantile activity. The trickle-down effects of global mercantilism affected spaces small and large. The investigation of the Erber highlights the domestic implications of global commercial expansion: ambitious city merchants reaped the rewards of exploratory voyages abroad without leaving London, while the lower sort of merchants competed to acquire more storage space to develop their small businesses in the squeezed city environment. ${ }^{16}$

\section{Acquisition of the Erber}

Like most of the 'great' livery companies, the Drapers had already accumulated a substantial estate by the early sixteenth century. Prominent members gifted moderatelysized properties to the Company, the rents of which were intended for charitable uses. However, surplus funds and profits could be channelled into corporate coffers and

\footnotetext{
${ }^{15}$ For further discussion of the role of the livery companies in early modern city development see my thesis: S.A. Milne, 'Merchants of the City: The London estate of the Drapers' Company, c.1540-1640' University of Westminster, PhD thesis, 2017.

${ }^{16}$ This idea was discussed in the conference paper: L. Haydon, 'Some outlandish fruits: foreign trade, domestic fruits', Performative Spaces, Society of Renaissance Studies, University of Southampton, July 2014.
} 
invested in plate or property. ${ }^{17}$ The Erber was one of two significant direct purchases made by the Drapers during the early 1540s which utilised bequeathed funds in order to expand the Company's estate.

In particular, it seems that it was the substantial bequest of Thomas Howell, a Draper in the Anglo-Spanish trade and former Company Warden, that allowed the Company to benefit from the property fall-out after the Dissolution of the Monasteries and the untimely death of associates of Henry VIII's. ${ }^{18}$ Howell was a notable figure in the Iberian cloth trade, regarded by David Harris as 'among the earliest Englishmen who traded directly with the Spanish possessions in the Caribbean'. ${ }^{19}$ Already successful by the 1520s, Howell relocated his business from Bristol to London, exemplifying the growing centralisation of English cloth trade on the capital. Fellow Draper and later Master of the Company, George Monox, also transferred to London, trading primarily with Spain and Portugal but in a triangulation of trade with the Levant, East and West Indies. By the mid-sixteenth century, London handled 90 per cent of English cloth exports, leading to the physical decay of cities such as Bristol as regional urban economies contracted. In 1538 Bristol's Mayor complained that buildings, the quay, and city walls had become vacant and even ruinous. ${ }^{20}$ Meanwhile, London was struggling with quite the opposite spatial problem, though it too was afflicted by a decline in the cloth-finishing industry in the second half of the sixteenth century. During this time prosperous members of the Drapers' Company traded in far more diverse goods because of the failures in the cloth industry. ${ }^{21}$

Taking advantage of the relatively favourable economic conditions of the 1540s, the Drapers' Company deemed the Erber a property suitable for their purposes on account of its size, location and reputation. Referred to as 'The King's Place' in early

\footnotetext{
${ }^{17}$ For detailed evidence of this see: W. Archer-Thomson, Drapers' Company: History of the Company's Properties and Trusts, (London: 1947)

${ }^{18}$ G. Williams, 'Howel, Thomas (c.1480-1537)' in Oxford Dictionary of National Biography (Oxford, 2004); online edn, Jan 2008. http://www.oxforddnb.com/view/article/62337 [Accessed online 5 Aug 2015]. For the protracted negotiations to retrieve these funds, which were pillaged during their transportation from Seville to London, see: DCA, MB1B, f.583, f.683, f.732 and MB1C, f.758.

${ }^{19}$ D. H. Slacks, The Widening Gate: Bristol and the Atlantic Economy, 1450-1700 (Oxford: 1991), 31

${ }^{20}$ Slacks, 'Widening Gate', 30.

21 'Textile industries since 1550', in A History of the County of Wiltshire: Volume 4, ed. E. Crittall (London, 1959), 148-182. British History Online: http://www.british-history.ac.uk/vch/wilts/vol4/pp148-182 [Accessed 26 February 2018].
} 
documents, the Erber's medieval origin as home to a string of important courtiers has been briefly attested to in Stow and Strype's accounts and expanded upon by C. L. Kingsford. ${ }^{22}$ The house was initially granted by Edward III to the Le Scrope family in 1341, passing to William Le Scrope, Earl of Wiltshire before 1399. It was consequently owned by Ralph Neville (Earl of Westmoreland), Richard Neville (Earl of Warwick), Richard Neville (Earl of Salisbury) and George Plantagenet (Duke of Clarence). ${ }^{23}$ On Henry VIII's accession to the throne the new King followed the pattern of his predecessors by gifting the property to a prominent member of his Court. At this time Margaret Pole, Countess of Salisbury, was the recipient. However, the Countess was beheaded on grounds of treason in 1541; her unfortunate execution was presided over by Lord Mayor William Roche, a Draper. When the property reverted back to the King it was quickly purchased by the Company and Roche himself was granted a tenancy of a tenement on the site in his later years. ${ }^{24}$

Less than a year after purchase of the Erber, in March 1543, the Company acquired the extensive former residence of Thomas Cromwell, located on Throgmorton Street in Broad Street Ward. As a result, the Drapers elected to move their corporate headquarters from their St Swithin's Lane Hall to their new Throgmorton Street purchase, making use of a considerable courtyard house and hall at the core of the property. ${ }^{25}$ Like the Erber, this site was large and diverse, but it included almost no accommodation for the lower sort, instead consisting of several large tenements, intended for the 'many of this said fellowship that do lack houses to dwell in' ${ }^{26}$ The size and value of the properties at Throgmorton clearly suited the purses and activities of those in the upper tier of the Company, although no one house matched the prestige and size of the Erber's principal house. The largest property in Throgmorton was leased for only a third

\footnotetext{
22 The National Archives (TNA), C 66/1489/1017; Stow, Survey, 229-238; J. Strype, Survey of London (London, 1720), 202; C.L. Kingsford, 'On some London houses of the early Tudor period' in Archaeologia 71 (1921), 17-54.

23 TNA, C 66/357, Membrane 12.

24 TNA, SC 6/HENVIII/6867; TNA, CC 397; TNA, PROB 11/39/79; Drapers' Company Archive (DCA), Renter Warden Accounts (RA) 1558-9, f. 12r; DCA, RA 1561-62, f. 22v; DCA, RA 1562-3, f. 22 v.

${ }^{25}$ DCA, MB1C, f.752

${ }^{26}$ DCA, MB1B, f.725, f.727, f.742
} 
of the price of the Erber's principal house. ${ }^{27}$ Schofield identified the Throgmorton model as one of three social outcomes of the dissolution of the monasteries, namely the development of 'mid-sized clusters of closely-grouped upper-class houses' ${ }^{28}$ The potential to group neighbours with shared business interests and networks together was critical to the appeal of the site to prosperous merchants, with the Company's decision to purchase the Throgmorton was driven by a concern that it should prove a 'both profitable and pleasant' investment. ${ }^{29}$ The precise nature of the 'profit' was not defined, although as astute businessmen, financial returns were an inevitable and reasonable motivation. On the other hand, the 'pleasant' qualities of the site were essential if the Company was to reputably associate itself with the site and attract the right sort of tenant. For nearly a century after acquisition, vacancies in the Erber and Throgmorton properties were nearly non-existent suggesting their instincts that these would be productive purchases proved correct.

Soon after its purchase in 1543, Drapers' Hall was well inhabited by middling sort merchants of the Drapers' Company, many of whom were associated with the Merchant Adventurers. By the beginning of the seventeenth century, tenants included merchants of the highest order and civic standing also involved with trading companies. In the 156080 s, properties in the hall were occupied by John Quarles (Draper, Merchant Adventurer), William Hobbes (Draper, Merchant Adventurer), and Sir Martin Calthorpe (Draper, Muscovy Company, Merchant Adventurers, Turkey Company, Venice Company, Alderman, Lord Mayor). ${ }^{30}$ From 1606 until at least the 1630s, William Towerson, Skinner, and prominent member of the Spanish Company, occupied a tenement in Drapers' Hall. ${ }^{31}$ Over this time his neighbours at the Hall included Isaac Jones (Merchant Adventurer), Sir William Cockayne (Skinner, Spanish Company, Eastland Company, Levant Company, Merchant Adventurer), Sir William Garway (Levant Company, Turkey Company, East India Company), Sir Henry Garway (Draper,

\footnotetext{
${ }^{27}$ For example, in the early 1580 s, the principal house of Throgmorton was leased for $£ 9$ whereas the Erber's principal house was rented for $£ 26$ (DCA, RA 1581-2, f.15v, f.16r).

28 Schofield, The Building of London, p.141

${ }^{29}$ DCA, MB1B, 727

${ }^{30}$ DCA, RA, 1565 - 66, f.16r; 1556 -57, f.13r; Johnson, History, Vol. II, 458-460; Brenner, Merchants and Revolution, 21, 32

${ }^{31}$ DCA, RA, 1606-7, p.11; 1630-31, p.15; Johnson, History, Vol. II, 458-460; Brenner, Merchants and Revolution, 21, 32
} 
Levant Company, Greenland and Russia Company, East India Company, Alderman, Lord Mayor) and Sir Morris Abbott (Draper, Levant Company, East India Company, Alderman, Lord Mayor). ${ }^{32}$ Between them, these men had trading connections with the Low Countries, France, the Iberian Peninsula, Muscovy, Eastern Europe, Barbary, Germany and the Levant. Members of the Drapers' Company were most closely involved with the Merchant Adventurers of London (established 1407), the Spanish Company (established 1530 and 1577) and the Muscovy Company (established 1555). ${ }^{33}$ These links are evident in the use and tenancies of both the Throgmorton Hall and the Erber in the sixteenth and early seventeenth centuries.

As one of a number of notably large courtyard houses increasingly held and maintained by the city companies, and favoured by merchant political elite, the Erber can be seen as a sort of local incubator for trade on expanded scales. Properties of this type could integrate housing with a company hall, not an entirely new proposition, but notable in the sixteenth and seventeenth centuries for how proactive the companies were in upholding and extending this arrangement. Such urban complexes could also prioritise the provision of separate accommodation for the Master of the Company or a similarly prominent mercantile tenant. Mercers' Hall (expanded accommodation acquired in 1542) and the Skinners' Hall (partially rebuilt in 1595 to create a dwelling house appropriate for a Lord Mayor from their Company) are but two examples of this formation. ${ }^{34}$ In the fifteenth century, when prosperous merchants were not averse to building city houses for themselves, Crosby Hall was developed, set deeply back from Bishopsgate and following the courtyard form. It was built for Master of the Grocers' Company and wool merchant, Sir John Crosby, and was occupied by three sixteenth century Lord Mayors and one Sheriff, most of whom held important mercantile interests. ${ }^{35}$ Its strong link with trading activity was reinforced in the 1620s and 30s, when Crosby Hall was utilised as the

\footnotetext{
${ }^{32}$ DCA, RA series; DCA, A X II 121; Brenner, Merchants and Revolution, 21, 32

${ }^{33}$ Rev. A. H. Johnson, History of the Worshipful Company of the Drapers of London, Vol II, (Oxford, 1922), 458-460.

${ }^{34}$ GL, MS 30708/1, Skinners Company, Court Book 1551-1617, f.56v.; MCA, Acts of Court ii, 1527-1560, f.clxxii-clxxiij; For more discussion, see: Milne, Merchants of the City, 106-119, and J. Kilburn-Toppin, 'Crafting artisanal identities in early modern London: the spatial, material and social practices of guild communities c. 1560-1640', PhD thesis, Royal College of Art, 2013.

${ }^{35}$ W. Thornbury, 'Bishopsgate', in Old and New London: Volume 2 (London, 1878), 152-170. http://www.british-history.ac.uk/old-new-london/vol2/pp152-170 [accessed 13 March 2015].
} 
headquarters of the East India Company. ${ }^{36}$ Houses such as these show that particular city buildings could be retained for mercantile use over a long term, flexibly intermingling or adapting to serve as commercial, corporate and domestic accommodation.

Buildings fashioned as livery halls were not infrequently used to host functions related to civic and trading corporations. The overlapping use of these spaces indicates the extent to which the membership of these groups was shared and the advantages of membership of one could transfer to benefit the membership of another. For example, the Mercers' Hall reserved a small room including a locked press for storage of monies and writings for the use of the Merchant Adventurers in the sixteenth century. ${ }^{37}$ Meanwhile, in 1557, Drapers' Hall was used by the Muscovy Company to host an important dinner with the Russian ambassador which marked the end of a period of negotiations regarding the Anglo-Russian trade. Although the Muscovy Company had its own base in the port of London, Drapers' Hall provided the appropriate setting for an impressive show of hospitality. Two leading members of the Drapers' Company at the time were investors in the Muscovy Company and led the preparations. ${ }^{38}$ Livery, civic and trading corporations were not just structurally intertwined but spatially bound together too.

Though corporate records suggest that pre-fire courtyard houses maintained by the city companies were an important building typology in the city, only fragmentary evidence of their architectural form and arrangement has survived. While detailed drawings of such buildings are rare, it is even more unusual to be able to relate this information to their adaptation and occupation over time. It is an extraordinarily fine plan, dated to 1596 and held by the Drapers, that marks the Erber out as an especially interesting case study. ${ }^{39}$ An unknown surveyor was paid $£ 36 \mathrm{~s}$. 8d. for the drawing, likely produced in relation to a legal challenge to the Company's ownership of the property.

\footnotetext{
${ }^{36}$ T C Dale, 'Inhabitants of London in 1638: St. Helen's within Bishopsgate', in The Inhabitants of London in 1638 (London, 1931), 69-70. British History Online: http://www.british-history.ac.uk/no-series/londoninhabitants/1638/pp69-70 [accessed 27 February 2018]; Foster, Sir W. (1913). 'The East India Company at Crosby House, 1621-38'. London Topographical Record. 8: 106-39

${ }^{37}$ MCA, Acts of Court iii, 1560-1598, f.131

${ }^{38}$ Johnson, History, Vol. II, 185; S. Alford, London's Triumph: Merchant Adventurers and the Tudor City (London, 2017), 88-90

${ }^{39}$ It has been suggested that the surviving plan may be a seventeenth century copy of an original 1596 plan. See: D. Gerhold, London Plotted: Plans of London Buildings c.1450-1720, S. O'Connell (ed.), (London, 2016)
} 
This case was heard in the Court of Exchequer in $1596-7 .^{40}$ The challenge was raised on account of the medieval grants of property, exchanges completed long before the Drapers purchased the Erber but still grounds for contestation of their rights to the property. The matter was in fact settled by the Queen in 1598 when she ruled in favour of the Drapers, overruling her own searcher, the notorious William Typper. ${ }^{41}$ Moreover, the Drapers' Company's administrative records allow the Erber to be traced in some depth from 1541 onwards. Through the Renter Warden Accounts and Minute Books, particular fragments of the building can be reconstructed in surprising detail, with tenants and small-scale rebuilding work identified. ${ }^{42}$ These sources offer insight into the discussions and decisions of governors of the Drapers' Company as they managed corporate property. The concerns and tensions implicit in these documents shed light, not only on the contribution of the Company to processes of change in the urban environment, but on the reasoning behind corporate action or inaction.

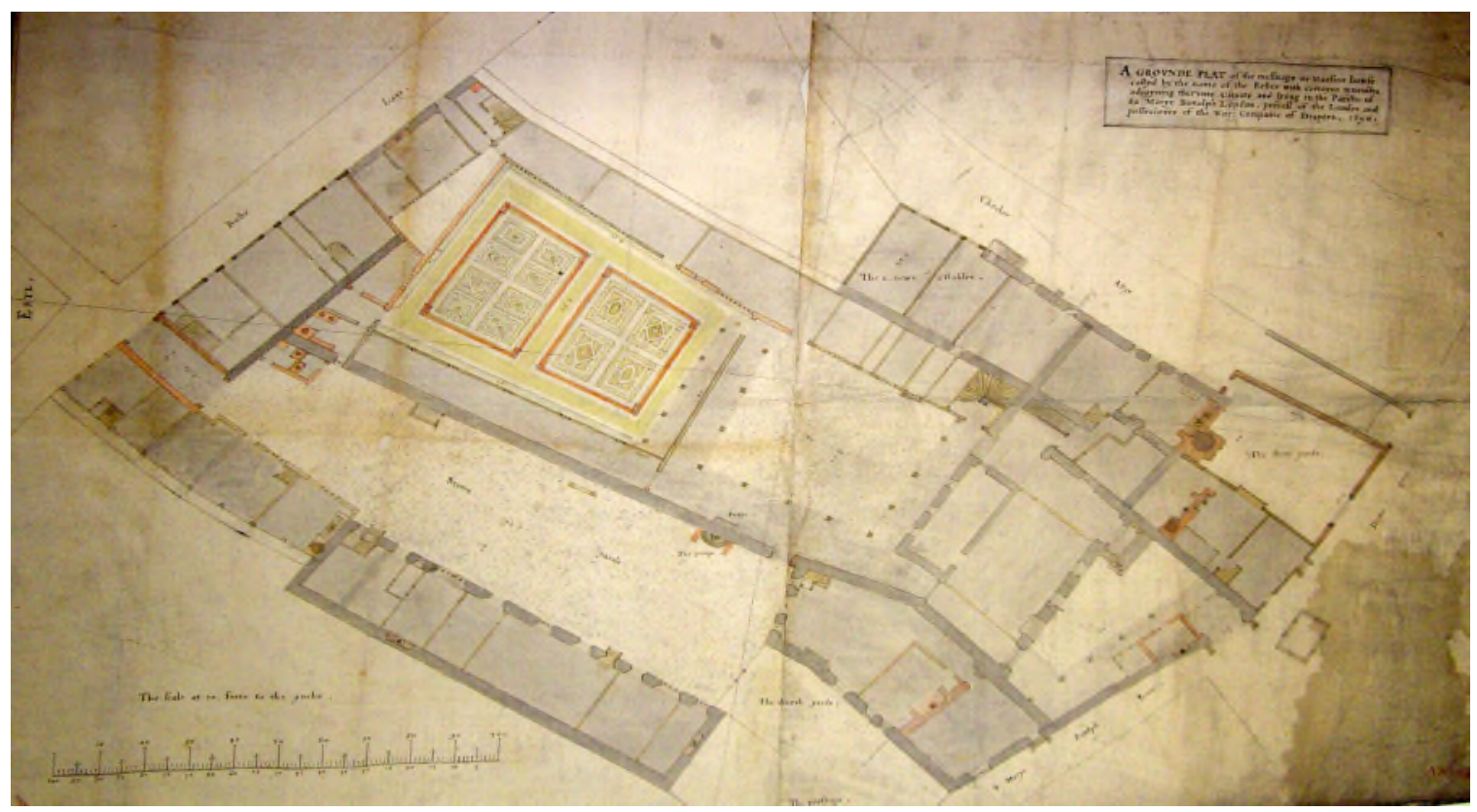

Fig. 2 - Anon. The Erber plan, 1596 (DCA, A X III 165)

\footnotetext{
${ }^{40}$ DCA, MB10, f.193r; DCA, MB11a. f.10r, f.13v.

${ }^{41}$ The case can be followed in the following documents: TNA, C 66/1489/1017; TNA, E 178/1382; DCA, MB10, f.222v, f.236v, f.238v; MB11a. f.10r, f.13v., f.34v., f.30r. Also see commentary in: T. Girtin, The Triple Crowns: A narrative history of the Drapers' Company 1364-1964 (London, 1964), 194-195

${ }^{42}$ Treswell's Clothworkers' study is a notable exception: J. Schofield, (ed.) The London Surveys of Ralph Treswell (London, 1987).
} 
The large coloured drawing of 1596 presents the Erber as a characteristically medieval urban mansion house constructed primarily of thick stone walls, with brick and wood infill (see fig. 2). Beyond the principal house, the plan reveals a network of internal courtyards and garden spaces. The quality of the carefully-rendered quadrant garden is strikingly embellished by the surveyor, indicating this was space of the utmost prestige and leisure. Lined with stone tenements and warehouses, the spacious long yard to the north-east is labelled 'Scott's Yard'. To the south of the main hall sat an open storeyard at the corner of Dowgate Hill and Carter Lane. A series of modular storage spaces and stables lined the lane. Through close observation of the form and building materials used, the drawing suggests that, although the courtyard arrangement was significantly upheld throughout the Drapers' ownership, parts of the Erber had undergone change and expansion over time in order to maintain its status both as a reputable house for a merchant of the highest calibre and as a hive for the commercial endeavours of more provincially-orientated merchants.

The investigation that follows examines the occupation and development of the house in three parts, firstly dealing with the principal house, then moving to the storeyard, and finally considering the Carter Lane elevation. In examining the Erber's appropriateness as an honourable home for important civic-minded city merchants, this paper proposes that the Drapers preserved the 'pleasant' qualities of the principal house in order to serve its wealthy mercantile leaders engaged in the performance of significant civic duties. It also suggests that the Company recognised the wider need to support its members' own building work, responding to the space shortage by ensuring a large storeyard was available to members, with materials on hand to facilitate the making of new storage spaces in the city. Lastly, the investigation considers the conditions under which the Company endorsed proactive development of their properties by mercantile tenants of the lower sort.

\section{Profitable and pleasant}

Bearing profitability in mind, it is notable that the Drapers ensured near continuous lets of all portions of the Erber for decades after its purchase. Between its 
acquisition and subsequent destruction in 1666, the principal house was occupied by a string of important London merchants associated to the Company, although not always drawn from its ranks. By providing suitable city-centre houses for ambitious merchants belonging to an increasingly globally-orientated socio-economic network, men who often also had the potential to serve in corporate and civic offices, the Company secured a stake in the future prosperity of London. Tenancy records reveal that from c. 1540-1630 all but one tenant of the principal house (see fig. 3) can be directly linked to exchanges on an international scale and many, particularly in the latter half of the century, served as city officers (see appendix 1).

Fig. 3. Re-drawing of 1596 plan by author. Extents of principal house highlighted. (LOCATED ON NEXT PAGE)

Upon transferral to the Drapers' Company, the first tenant installed in the principal house of the Erber was John (or Jan) Over, former resident of Antwerp, where he acted as leader of the Merchant Adventurers. He was described by two Dutch and Italian merchants during his Antwerp tenure as "a man of good fame, realistic and of means", yet he does not seem to have been a member of the Drapers. ${ }^{43}$ For those operating at an international scale, membership of a London livery company was not necessarily synonymous with membership of a well-established trading corporation such as the Merchant Adventurers. However, a level of overlap between corporations was advantageous, allowing the benefits of one group more easily transferred to those in another. Despite his important role in Antwerp trade which would have inevitably involved contact with members of the Drapers' Company through the trade of cloth, Over's mercantile activity whilst in occupation of the Erber is not clear. His tenancy was followed by John Kendall and his widow, a couple about whom even less can be traced. ${ }^{44}$

Taken together, the next few tenants of the Erber's principal house indicate that, at least in the mid-sixteenth century, the Company was amenable to the idea that corporate property could be used to nurture the extending networks of trade in which its leading

\footnotetext{
${ }^{43}$ O. de Smelt, De Englelse Natie Te Antwerpen in De 16e Eeuw (1496-1582), Vol II, (Antwerp, 1950), 137,561

${ }^{44}$ DCA, RA 1556-7, f.13, RA 1557-8, f.25, RA 1558-9, f.12, RA 1559-60, f.9
} 


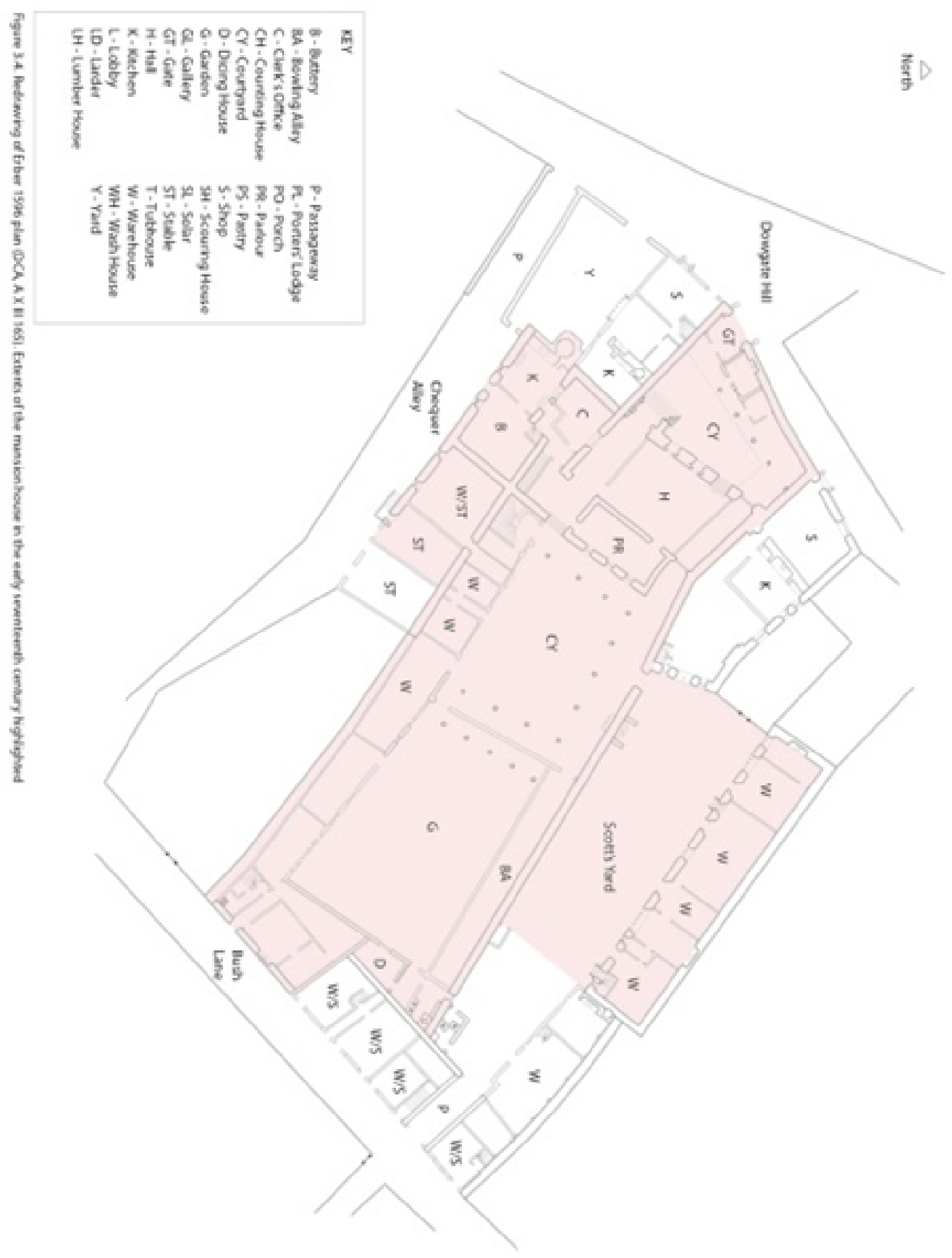


members were increasingly caught up. Thomas Howell's fortunate bequest of 1538, only made possible through his extensive trade with Spain, specifically Seville, demonstrated that some prosperous members of the Company were already deeply engaged in AngloSpanish trade in the early decades of the sixteenth century. The Spanish association came into sharp relief at the Erber from the 1560s onwards. In this decade and the next, two merchants and 'spies' for the King of Spain consecutively occupied the principal house. Howell's bequest, the strength of the Spanish-Portuguese trade at this time, and the related activity of later tenants, suggest this must have been a profitable and likely strategic let at the time the tenancy was granted, even though the direct link between these merchants and the Drapers is again unknown.

It is clear, however, that both Antonio de Guerras and Luis de Paz became agents for Philip II of Spain sometime between 1540 and 1560 whilst resident in London. ${ }^{45}$ For de Paz and de Guerras, it appears the house was a cover, suitable both for the operation of their business activity, as well as the representation of their status as prominent, respectable mercantile men. De Paz' tenancy of the Erber began in 1560 and it is said he operated 'in the guise of a merchant' when he was sent by the Spanish Ambassador from London up to Scotland in 1564. De Paz was followed in 1562 by de Guerras, who was an active Spanish merchant in London from at least the 1540s. In 1545, for example, he was importing French goods on a ship called the 'Anna of Barsalana'. ${ }^{4}$

De Guerras secured the transferal of de Paz's tenancy on the basis that he would spend $£ 100$ on reparations, but the extent to which he honoured his promise of improving the property is unclear and the Drapers' records imply that little work was undertaken. ${ }^{47}$ Soon after his arrival, however, the tumultuous relationship between Spain and England caused the alien merchant to spend the first of two periods of imprisonment in the Tower of London under charges of spying. Agents of Queen Elizabeth seized the Erber and the house was ransacked, drawing unwanted attention to the Erber once again. Catholic

\footnotetext{
${ }^{45}$ M.A.S. Hume (ed.), Calendar of Letters and State Papers of Spain Presented Principally in the Archives of Simancas, Vol. 1 (London, 1892), 399.

$46 \mathrm{Ibid}$; M.A.S. Hume (ed.), Calendar of Letters and State Papers of Spain Presented Principally in the Archives of Simancas, Vol. 2 (London, 1894) 348, 353; J. Gairdner and R.H. Brodie (eds.), Letters and Papers, Foreign and Domestic, Henry VIII, Vol. 20, Part I, (London: Her Majesty's Stationery Office, 1905), 457.

${ }^{47}$ DCA, MB5, f.243; DCA, MB8, f.28r, f.33v.
} 
images and gilt carvings taken from the house were paraded through the streets of London on a crowded market day. In a highly-visible act of incitement against the Spaniards, the controversial spoils were separated in half and burned outside the Erber on Dowgate Hill and in an unspecificed market-place (probably nearby Cheapside or the Stocks), piled on cart-wheels. ${ }^{48}$ On release from the Tower, for the next three years de Guerras remained in self-imposed house arrest 'without daring to appear on the streets. ${ }^{49}$ During this time, the Company suspected further neglect of their valuable property; the promised reparations remained undone and Company officers were denied entry by de Guerras. The merchant's second imprisonment in the Tower soon led to his dismissal from England altogether in 1570 and the property was then granted to future Lord Mayor and Draper Thomas Pullison. Such was the extent of disrepair that Pullison agreed to rebuild and alter the property within seven years for a sum of 1000 marks. ${ }^{50}$ De Guerras reportedly died in relative obscurity in Tarragona, whilst de Paz may have been one of the Knights Hospitaller who died in the 1565 Siege of Malta, serving Philip II. ${ }^{51}$

After nineteen years in the hands of Spanish merchants, in 1579 the Erber's principal house was duly transferred into the hands of an internationally ambitious London merchant, Thomas Pullison. His residency was to be emblematic of a string of tenants who entered the Erber just before, or even during, their first year in an enlarged civic role. Pullison himself secured a lease only a couple of years before his term as Lord Mayor. ${ }^{52}$ Unlike de Paz and de Guerras, the Draper seems to have made good on his promise to renovate the property. John Stow noted that the Erber was 'new builded' by Pullison, though the precise nature of the changes made to the existing building fabric is unclear. ${ }^{53}$ Surveying the 1596 plan, there is some evidence of the construction of a new kitchen to the south of the great hall, presumably to enable the hospitality intrinsic to the

\footnotetext{
${ }^{48}$ Hume, Calendar, Vol. 2, 148.

${ }^{49}$ Hume, Calendar, Vol. 2, 353.

${ }^{50}$ DCA, MB9, f.98v-99r, f.142v. The Drapers also contributed $£ 40$ towards fitting up the house for his mayoralty as was their custom: DCA, Wardens' Accounts (WA), 1584-5, f.6r.

${ }^{51}$ R.E.G. Kirk and E. F. Kirk eds. Returns of Aliens dwelling in the city and suburbs of London, from the reign of Henry VIII to that of James I (Aberdeen, 1908), 158; P. Gentil, Trattato Del Successo Della Potentissima Armata del Gran Turcho Ottoman Solimano, (Rome: 1565), xlix

${ }^{52}$ Evidence of Pullison's use of the house for his duties as Lord Mayor can be found: London Metropolitan Archives (LMA), COL/CC/01/01/021, f.143r, f.149v, f.445v.

${ }^{53}$ Stow, Survey, 231.
} 
mayoralty, but little else that suggests any significant internal re-configuration on the ground-floor. Typical for those serving in high civic office, during his term as Lord Mayor, Pullison was granted special rights to the water conduit at the top of Dowgate, seen on the Erber drawing. This enabled a private quill to pipe water into his house, again aiding the dispensation of hospitality. The condition for this privilege was that he personally bear all the costs of installation. ${ }^{54}$ After Pullison, well-known admiral and honorary Draper, Francis Drake was admitted to the principal house after the defeat of the Spanish Armada at Plymouth and his expedition to Cadiz. In 1589, he led an expedition to Portugal whilst holding tenancy of the Erber and vacated the property on completion of a second term serving as MP in $1593 .{ }^{55}$

Drake's occupation of the same house was sandwiched between the tenancies of 'city magnate' Paul Banning and Thomas Pullison, both of whom were associates from the Spanish Company. ${ }^{56}$ A member of the Grocers' Company, Banning's entry to the Erber corresponded with his election to the office of Alderman in the year 1592-93. Although moderately involved in his livery company and urban governance, his focus was on his commercial exploits. Head of a large household of employees and servants, Banning has been described by I. Habib as a typical member of a 'trans-national AngloSpanish merchant community' and his activity accounted for 94 per cent of imports from the Levant. ${ }^{57}$ Whilst Pullison, as elder merchant, was still a member of the longestablished Merchant Adventurers, whose influence was fading, Banning took up with the new East India Company, whose star was rising. But more united these two men than divided them. London-based Banning and Pullison were simultaneously members of livery companies, city officers, and important leaders of several newly-formed trading companies. Thus, to differing degrees, the pair appear to represent men of the new mercantile elite, a foreshadow of what was to come. While tenants who followed Pullison and Banning did not implicate themselves so heavily in trade, there remained a

\footnotetext{
${ }^{54}$ LMA, COL/CA/01/01/023, f.89r.

${ }^{55}$ DCA, RA 1590-1, f.15r.; 'Francis Drake' in The History of Parliament: the House of Commons 15581603, ed. P.W. Hasler (London, 1981)

${ }^{56}$ I. Archer, 'Bayning, Paul (c.1539-1616)', in Oxford Dictionary of National Biography (Oxford, 2006).

${ }^{57}$ Ibid; I. Habib, Black Lives in the English Archives, 1500-1677 (Aldershot, 2008), 79; I. Scouladi (ed.) Returns of Strangers in the Metropolis, 1593, 1627, 1635, 1639: A Study of an Active Minority, (London, 1985).
} 
correlation between tenancy, livery company membership and service in a civic role. East India Company investor and member of the Company of Leathersellers, Edward Barkham's tenancy in 1611 coincided with his admission to the office of Sheriff. He then progressed to become Lord Mayor in 1621-22 while still in occupation of the Erber. ${ }^{58}$ This role required his transferal from the 'lesser' Leathersellers to the 'greater' Drapers' Company, a switch that also effectively ensured the Erber would serve as his residence for the term of his mayoralty. ${ }^{59}$ Later residents included Lord Mayors of 1636-37 (Leatherseller turned Fishmonger, Edward Bromfield) and 1657-58 (Skinner, Richard Chiverton) reinforcing the Erber's reputation as an appropriate house for city leaders. ${ }^{60}$

\section{The Storeyard}

The continued occupation of the principal house of the Erber by merchants serving in high civic office in the later sixteenth century suggests that the property effectively supported men in performance of their civic duties, especially in regards to hospitality, thereby ensuring the city's honour was upheld. It also offered functional spaces that would have facilitated the business of trade, namely a suitable range of warehouses and places of storage. Logistics for the processing and exchange of goods within the wider city were however not always straight forward. Disputes between porters and merchants were not unusual, existing spaces to receive and send out traded things were in greater demand, and roads were increasingly clogged with traffic. ${ }^{61}$

In terms of location, the Erber's position close to Thames Street, an important east-west trajectory through the city, and elevation to Dowgate Hill, placed it within convenient proximity to key thoroughfares well-used by porters and carts. Congestion on routes such as Thames Street was frequent as ever-more goods in transit were ferried here and there. London chronicler, Henry Machyn accounted for the shocking death of a carter in 1562 by recalling how a glut of carts that had halted traffic on the road he was

\footnotetext{
${ }^{58}$ DCA, RA 1592-3, f.13r; RA 1612-13, f.17r.

${ }^{59}$ DCA, RA 1621-2, f.19r.

${ }^{60}$ DCA, C31/1-2; DCA, MB14, f. 209r.

${ }^{61}$ Ward, Metropolitan Communities, 58-63; W. Stern, The Porters of London (London, 1960); J. Schofield, 'The Topography and Buildings of London' in Material London, ca. 1600, L. Orlin (ed.) (Philadelphia, 2000), 297-321, 317.
} 
travelling on caused one road user's anger and frustration to turn murderous. ${ }^{62}$ Running roughly parallel to Thames Street and along the Erber's southern boundary, Carter Lane (later known as Chequer Alley) was likely a resting place for the city's porters, carters and their related tackle. The Salisbury records from the early sixteenth century noted temporary fastenings for horses, stables, and licenses for rented individual carts. Latterly, de Guerras and Barkham ensured existing stables in Carter Lane, then not allied to the Erber, were included in their leases, so the association of this passage with transportation even if its character was somewhat in flux. ${ }^{63}$

There is no evidence which distinguishes precisely how the warehouses of the Erber were used, but their multitude and arrangement indicates that on-site storage was a priority for occupiers of the principal house. Subsidiary tenements, multiple entrances and connected courtyards enabled the Erber to function as an effective 'live-work' space prudently attuned to mercantile needs (see figure 3.4). An entry gate between the Erber's backyard and Scott's Yard allowed for fluidity between the two distinct spaces, likely allowing for the articulation of differing patterns of use. A number of tenements and warehouses in Scott's Yard were included in the lease of the principal house. ${ }^{64}$ Goods might have arrived via Bush Lane into Scott's Yard for checking by factors before more valuable or delicate merchandise was directed to the rooms surrounding the Erber's first rear courtyard. ${ }^{65}$ A rare 1577 inventory of another city mansion house held by a mercantile Lord Mayor records that a great warehouse, a fish house, and a spice house were all parcelled into the property. John Schofield's archaeological study of a mercantile Grocer's property by the Thames concluded 'that rooms and spaces were carefully distinguished by function in these house-and-business complexes; and that various solutions for the increasing problem of warehouse storage were being attempted. ${ }^{66}$ For,

\footnotetext{
${ }^{62}$ H. Machyn, A London Provisioner's Chronicle, 1550-1563, by Henry Machyn: Manuscript, Transcription, and Modernization, R. W. Bailey, M. Miller, C. Moore (eds.) (University of Michigan, 2015), f.156r. http://quod.lib.umich.edu/m/machyn/ [Accessed 3 Feb 2015.]

${ }^{63}$ Stow, Survey, 231; TNA, SC 6/HENVIII/2082; DCA, RA 1563-4, f.20v; RA 1624-5, f.18r.

${ }^{64}$ DCA, RA 1595-6, f.11r.

65 The comparatively generously sized spaces depicted on the plan, alongside the lack of hearths in these larger rooms, suggest ground floor warehouses.

${ }^{66}$ F. Fairholt, 'On an inventory of the household goods of Sir Thomas Ramsey, Lord Mayor of London, 1577', in Archaelogia, 40 (1866), 311-42; J. Schofield, P. Pearce, with I. Betts, T. Dyson, G. Egan,
} 
as well as absorbing an ever-increasing proliferation of imported and exported goods, city spaces may have become more specialised around trading activities and the containment of goods.

Although records offer little direct insight into the development of the Erber's storage spaces, it is clear that other buildings of this nature held by the Drapers' Company were increasingly subdivided and expanded. Tenants of all sorts tried their hand in adapting properties to extend their commercial capacity, creating new doorways, partitions, and cellars to accommodate the reception, storage, and dispensation of goods. Garrets and penthouses were added and open yards were covered over by low warehouses. ${ }^{67}$ The importance of maintaining spaces that were well-built and secure in order to protect merchandise also led to improvements; existing rooms were rebuilt in brick, given heavier doors and locks, and windows extra iron bars, to ease concerns. ${ }^{68}$ While space above ground was frequently covered over and buildings grew taller, the city inevitably developed its underground capacity too. John Evelyn evocatively observed the valuable subterranean network of spaces that lodged beneath many of London's buildings as he walked around in the post-fire city. ${ }^{69}$

The adaptation of existing buildings, often to accommodate more traded goods as much as to improve domestic spaces, was reliant on the acquisition of building materials at a reasonable price. Recognising the benefits of retaining a quota of materials 'in store', the Drapers sought to serve its members by increasing its capacity to stockpile building materials for corporate and individual use. In 1555 the Company elected to create a storehouse, enlarging the ground-floor gallery of its Throgmorton Hall to 'lay in boards and timber'. In the same year the cellars below the gallery were extended and this space was given over to tenants of the Company's capital house at the Hall. ${ }^{70}$ The Drapers were not alone in developing such spaces. In the 1550s the Merchant Taylors also enclosed a

'Thomas Soane's buildings near Billingsgate, London 1640-66' in Society Post-Medieval Archaeology 43, no. 2 (2009) 282-341, 331.

${ }^{67}$ L. Orlin, Locating Privacy in Tudor London (London, 2007), 286-9; DCA, MB8, f.61r; MB13, f.11r, f.175r; DCA, RA 1563-4, f.24r; RA1597-8, f.12r.

${ }^{68}$ DCA, RA 1563-4, f.25r; RA 1570-1, f.19v.

${ }^{69}$ J. Evelyn, The Diary of John Evelyn, Vol 2., W. Bray (ed.) (New York and London, 1901), 24; Also see:

L. Orlin, 'Temporary lives in London lodgings', in The Huntington Library Quarterly 71 (2008), 219-242, 223.

${ }^{70}$ DCA, MB5, f.118r. 
new storeyard within the boundary of their hall and the Mercers too had appointed a storeyard or 'timberyard' so that materials could be purchased 'as convenient and reasonable price as may be had' ${ }^{71}$

Identifying an opportunity to develop a larger storeyard, a site at the Erber was surveyed in 1557. Four experienced Drapers were appointed to view the "void place at Dowgate beside the Erber' in order to ascertain 'whether it will be a mete place for a store house for this fellowship or no'. ${ }^{72}$ It was not until several years later that action was finally taken and the Drapers resolved to re-claim the yard from Brown, their 'tenant-atwill' whose occupation could therefore be revoked at short-notice. However, Brown was not cooperative and a case was lodged against him, which resulted in his forcible eviction; the decision of the jury and witnesses was notably taken after a dinner at Drapers' Hall. ${ }^{73}$ Soon after, a bricklayer and five labourers constructed a new boundary brick wall and the base of the storehouse, after which the Company's Carpenter, who was to oversee the day-to-day running of the completed storeyard, finished the building frame. ${ }^{74} \mathrm{~A}$ 'great gate' of brick faced onto Dowgate, in which a stonemason, Phillip Paskin, was paid to set up a stone carving of the Drapers' Arms. Over the following decades, further constructions progressively filled more of the yard to accommodate the activity of carpenters and the stockpiling of building materials (see figure 5.3). By 1590, the Company had passed on its lease of the storeyard directly to William Bradshaw, the Company's Carpenter, showing just how comfortable the arrangement had become with his oversight. ${ }^{75}$ Tools were stored on site, wainscots were deposited in penthouses, 'great logs of timber' were temporarily lodged outside the gate ready for 'slitting' and sawing across an excavated pit. $^{76}$

Leaders of the Drapers' Company utilised their personal trade connections in service of the Company, frequently buying in materials for storage in the yard for

\footnotetext{
${ }^{71}$ C.M. Clode (ed.), Memorials of the Guild of Merchant Taylors of the Fraternity of St. John the Baptist in the City of London (London, 1875), appendix C: to memorial III; Mercers' Company Archive (MCA), Acts of Court ii, f.273 d.

${ }^{72}$ Ibid. f.219.

${ }^{73}$ DCA, RA5 1564-65, f.10v-11r.

${ }^{74}$ DCA, RA 1564-65, f.21v-22r.

${ }^{75}$ DCA, RA 1589-90, f.14v.

${ }^{76}$ DCA, RA 1575-6, f.9r, f.18v; RA 1576-7, f.10r; RA 1580-1, f.9v. In 1615-6 the Rental Accounts still referred to a working saw pit in the yard at Dowgate: DCA, RA 1615-16, f.34r.
} 
eventual corporate use or deployment by other members. Warden of 1578-79 and 158283, William Megges was noted to have imported 200 wainscots intended for use in the refurbishment and upgrade of the Company parlour and roof at the Throgmorton Hall, coinciding with the construction of his own house in Whitechapel. ${ }^{77}$ His name consistently appeared in the port books of London in relation to the importation of wainscots, hops, oil, and soap ashes from the Low Countries. ${ }^{78}$ In 1579-80 an interesting tally or 'memorandum' outlined those implicated in the use of materials stockpiled in the storeyard. Five of the nine debtors were Drapers and also members of Company's governing Court. Among many examples, Thomas Pullison was recorded to 'oweth upon this account' weather board, hearth lath, double quarters and ragged stones. $\mathrm{Mr}$ Thorowgood, also a Draper and Warden, 'owed' a similarly large quantity of materials. Another Warden, Mr Heardson, owed $£ 517 \mathrm{~s}$. spent on quarter boards used on housing 'for the poor of the company'. ${ }^{79}$ Company stores therefore also ensured mercantile members had quick access to building supplies for both corporate and their own private projects, on the condition they return in kind or cash the value of the goods used, and with the assumption that these men would use their trading connections and business acumen to acquire materials for corporate use on favourable terms when needed. ${ }^{80}$

There is evidence that the equilibrium between corporate and individual gain implicitly held in balance in these corporate spaces could be unsettled. One instance of a Warden forcibly commandeering a storage space at Throgmorton demonstrates the difficulty in finding appropriate warehousing in the city, but also the potential for Company leaders to test the extent of their privilege. Claiming 'extreme necessity', in 1638 Warden, Merchant Adventurer, and French Company member Thomas Bewley was recorded to have surreptitiously taken occupation of the cellar under the gallery of the Company Hall to store wine, almost certainly imported from continental Europe, for commercial purposes. ${ }^{81}$ Carts rattled continually through the highly-prestigious courtyard and, as the cellar was often used late into the night with candles, the fire risk this posed

\footnotetext{
${ }^{77}$ DCA, MB8, f.223r, f.235r; MB9, f.4v; Tower Hamlets Local History Library and Archive, $\mathrm{P} / \mathrm{SLC} / 1 / 17 / 45$.

${ }^{78}$ B. Dietz (ed.), The Port and Trade of Early Elizabethan London: Documents (London, 1972).

${ }^{79}$ DCA, RA, 1579-80, f.20v.

${ }^{80} \mathrm{Ibid}, \mathrm{f} .21 \mathrm{r}$.

81 'Thomas Bewley' in P. Boyd, Roll of the Drapers' Company (Croydon, 1934)
} 
was a pressing concern. The Court of the Drapers ordered Bewley to leave the cellar as soon as possible, which he did, and the Warden was not further reprimanded for his indiscretion. ${ }^{82}$ This incident illustrates the high value of secure storage spaces and the temptation to capitalise on the spatial privileges of corporate office in pursuit of personal gain.

\section{Middling merchants}

In the densifying built environment, merchants of many sorts recognised the potential of marginal land to support the development of profitable enterprise. The Drapers' accounts show that Carter Lane was narrowed as constructions built up along its edges in a response to the struggle for more city-centre storage spaces. Here citizens of the middling sort, involved in domestic distribution channels upon which wider networks of trade relied, acquired and built on small sites facing onto the Lane. Their activity embeds Stow's assertion that London was 'the principal store house, and staple of all commodities within this realm' at an intensely local level. ${ }^{83}$ For as global trade expanded, domestic exchanges did not subside; rather, London became more central to English trade and commerce than ever before. Middling merchants primarily implicated with domestic exchanges competed for storage space in the city or sought to create it, just like those merchants trading at a global scale. The progressive enlargement of existing buildings and construction of new storage spaces on the Carter Lane site began with a singlestoried warehouse, a tenement called 'the Chequer' (easily confused with the Chequer Inn), and a void space or garden facing onto the Lane (see figure 4.8), though the strip of partly built-upon land was depicted as a blank space on the 1596 plan owing to its divergent ownership history. ${ }^{84}$ On this side-street, the agency of the middling merchant taylor Thomas Jackson and his associates indicates how the Drapers allowed for profitable development of their properties if it did not interfere with its prized 'pleasant' spaces. ${ }^{85}$ Smaller scale commercial activity could shape marginal spaces and operate in close proximity to more prestigious spaces. In upholding the diversity and complexity of

\footnotetext{
${ }^{82}$ DCA, MB13, f.324r-324v.

${ }^{83}$ Stow, Survey, 12.

${ }^{84}$ TNA, SC 6/HENVIII/6867; SC 6/HENVIII/2086.

${ }^{85}$ For confirmation of his status as a merchant taylor see: DCA, MB9, f.128; TNA, PROB 11/105/357.
} 
the city's built environment, the Drapers, as exemplar of a number of livery companies, implicitly supported the emergence of London as a critical centre for mercantile exchanges at both provincial and the global scales. Indeed, the two were conceptually and spatially interlocked (see fig. 4).

Fig. 4. Re-drawing of 1596 plan by author. Probable site of Jackson's development highlighted. (LOCATED ON NEXT PAGE)

The detail of Thomas Jackson's accumulation of accommodation shows that, for merchants of his level, perseverance and opportunism were useful attributes in the search for enlarged commercial space. In 1563 Jackson began his tenure at the Erber as lessee of a single tenement, paying $£ 4$ in rent. The tenement (marked as site 2 on the schematic diagram below, see fig. 5), associated to the Chequer, but not the Chequer Inn itself, was formerly occupied by John Jackson, possibly a relation. ${ }^{86}$ Over a forty-year period, Thomas Jackson worked to significantly expand his accommodation from this base. The first expansion on this thin strip of land occurred in the 1560s and was undertaken not by Jackson, but by his neighbour, a Clothworker named Nicholas Small. Small added another floor to his existing one-storey warehouse located just to the west of Jackson's house (marked site 1). This enlargement effectively doubled Small's rent. ${ }^{87}$ The internal spaces of this building were then subdivided and added to by the next tenant, Nicholas Parkinson, in the 1570s. As the warehouse expanded in size once more, the Drapers imposed a further rent hike, much to Parkinson's dismay. After threatening to abandon his let, Parkinson appears to have acquiesced, demonstrating that the Drapers held the upper hand. ${ }^{88}$ This proactive tenant may also have been responsible for the building of two new stables and lofts which had been constructed to the west of site 1 and partially depicted on the 1596 plan. ${ }^{89}$ Another lease for the same section of property in 1648

\footnotetext{
${ }^{86}$ DCA, RA 1564-5, f.20v.

${ }^{87}$ DCA, RA 1563-4, f.20v. For confirmation of Clothworker status also see: D.J. Hickman, 'The religious allegiance of London's ruling elite, 1520-1603', UCL, Ph.D. thesis, 1995, Appendix 2.

${ }^{88}$ DCA, MB9, f.98v, f.100r; DCA RA 1581-2, f.15v-16r.

${ }^{89}$ DCA, RA $1607-8$, f.21r.
} 
describes the same accommodation as 'one stable with a coach room in the same and a hayloft and

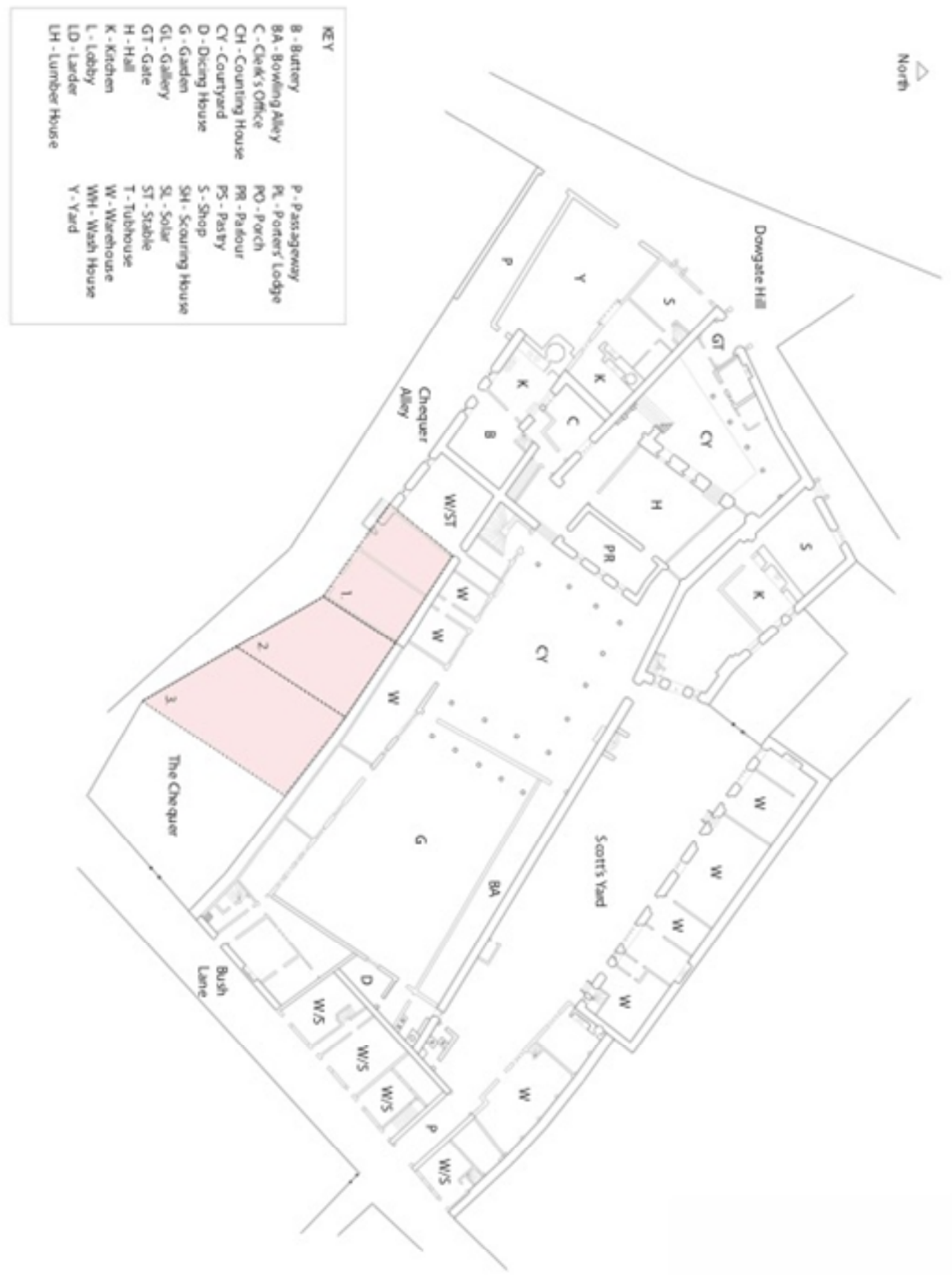


little chamber over the same', indicating that the space experienced further adaption by the mid seventeenth century. ${ }^{90}$

Fig. 5. Diagram indicating the progression of development on Carter Lane. Upper floors are represented by internal boxes. (LOCATED ON NEXT PAGE)

Thomas Jackson began conglomerating a larger proportion of the accommodation either side of his tenement in 1579, securing a lease of what had become 'the small storeyard at Dowgate' (site 3), an addition to the 'great' storeyard facing onto Dowgate Hill, for 40 s. per annum. His intentions were clearly to develop the yard for he wasted no time in petitioning the Drapers for license to build on his newly acquired land. Jackson pursued this project as a joint venture with Henry Fawlks, a prosperous local grocer. ${ }^{91}$ Representing the partnership, Jackson 'made offer to new build the stable which would cost him about the sum of $£ 10$ ' upon the 'void ground or old storeyard' ${ }^{92}$ Drawing on descriptions from later years, the building work undertaken by Jackson and Fawlks on the 'little' storeyard was alternately referred to as 'rooms in the yard' 93 , 'diverse other rooms and lofts in the yard with part of the new building', ${ }^{94}$ and also 'the new building and store yard'. ${ }^{95}$ This suggests some element of the open yard remained in spite of the construction of enclosed storage spaces on much of the land. Two years after Jackson's development of the small storeyard, he acquired the warehouses and rooms previously developed by Parkinson to the west of his original tenement (site 1). As the tenant or cotenant of all three sites, Jackson maintained his aggregated group of housing, warehouses, and stables, totalling a yearly rent of $£ 86 \mathrm{~s} 8 \mathrm{~d}$, for more than twenty years until his death in $1606 .{ }^{96}$ Yet a further subdivision was made after Jackson's death which led to the formation of three separate properties on the site of his former tenement. Likely the

\footnotetext{
${ }^{90}$ DCA, C 32.

${ }^{91}$ DCA, RA 1581-2, f.15v-16r. See: R.G. Lang (ed.), Two Tudor Subsidy Rolls For the City of London 1541 and 1582 (London, 1993).

92 DCA, MB9, f.128r, f.152r-3r; DCA, RA 1579-80, f.16v-17r.

${ }^{93}$ DCA, RA 1594-5, f.9v.

${ }^{94}$ DCA, RA 1595-6, f.11r.

95 DCA, RA 1597-8, f.10v.

${ }^{96}$ DCA, RA 1605-6, f.24r.
} 


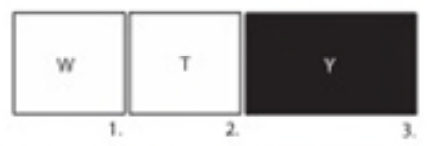

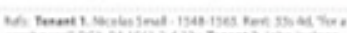

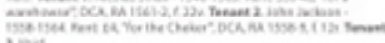

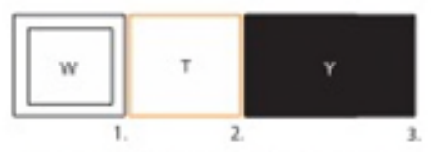

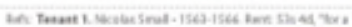

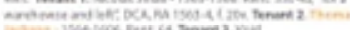

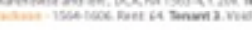

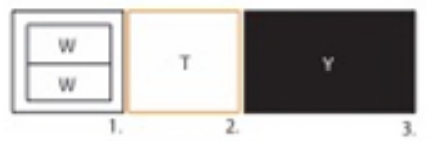

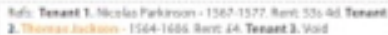

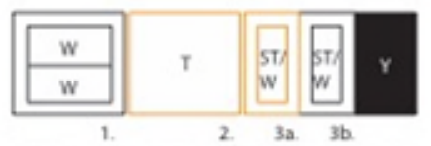

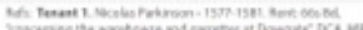
(A)

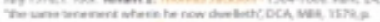

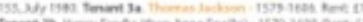

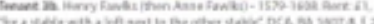

\begin{tabular}{|c|c|c|c|c|}
\hline$w$ & & & & \\
\hline$W$ & 1 & $w$ & $w$ & \\
\hline
\end{tabular}

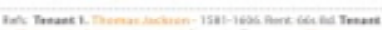

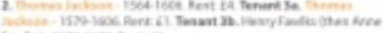

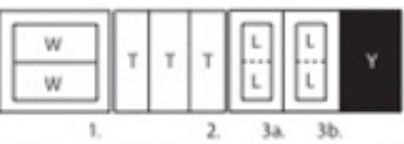

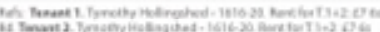

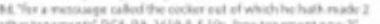

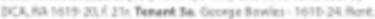

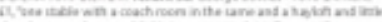

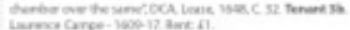

Phase 1, c. 1548-1563

Phase 2, c. 1563-1566

Phase 3, c. 1566-1577

Phase 4, c. 1577-1581

Phase 5, c. 1581-1606

Phase 6, c. 1616-1624

Phase 4, c. 1577.1581

Phases, c.1581-1606

KEY
$\mathrm{L}$ - Loft
$5 T$ - Stable
$\mathrm{T}$ - Tenement
$\mathrm{W}$ - Warehouse
$Y$ - rard
- - Thomas lacksoms Tenancies
-All nets. to DCA, RA unless
otherwise stated.

otherwise stated.

(1)

Phase 6, C. 1616-1624 
accommodation was let out separately for greater profit. ${ }^{97}$ In this way Carter Lane was consistently multiplied and compartmentalized, capitalizing on the location of the Erber and the 'slack space' surrounding it. Stow's Survey noted that Carter Lane had become known as Chequer Alley by 1603. The change from Lane to Alley carrying with it negative connotations of poor quality overdevelopment. ${ }^{98}$

\section{Conclusion}

Few would contest Derek Keene's assertion that trade was 'the prime force which conditioned the reordering and rebuilding of the [post-fire] city'. ${ }^{99}$ Yet for Brenner, reflecting on an earlier period around 1640, 'long-term processes making for the transformation of English trade, at work since the middle of the sixteenth century, were accelerated rather suddenly.' ${ }^{100}$ Although far less easily identifiable and visually impacting, this study proposes that the proliferation of small-scale adaptions to buildings held by livery companies in the sixteenth and early seventeenth centuries was spatially no less significant than the large-scale rebuilding of the city after 1666. Close observation of the Erber reveals something of the incremental developments that characterized the densifying landscape of the city. Lofts, warehouses, garrets, cellars, and storeyards were progressively built into and hewed out from the existing building stock and developed as extensions and re-appropriations of spaces already programmed or under-utilised. The case of the Erber supports the view that the spatial and institutional patterns for economic growth were already established by 1640 . Embedded within the urban environment, the accumulation of such tweaks to existing structures facilitated the operation of new trading ventures from the heart of the city. The use and occupation of the Erber demonstrates how a range of urban actors not only responded to global economic forces but negotiated them at intensely local scales. London was therefore already set on a trajectory of re-

\footnotetext{
${ }^{97}$ DCA, RA 1618-19, f.18r; DCA, RA 1619-20, f.21r.

${ }^{98}$ Stow, Survey, 204; For discussion of concerns of the Mercers see: MCA, Acts of Court iii, 1560-1598, f.232.

${ }^{99}$ D. Keene, 'Growth, modernisation and control: the transformation of London's landscape' in P. Clark, R. Gillespie (eds.), Two Capitals: London and Dublin, 1500-1840 (Oxford, 2001), 7-38, 30.

${ }^{100}$ Brenner, Merchants and Revolution, 22-23
} 
calibration around ever-increasing scales of mercantile activity long before the Great Fire forced a more obvious transformation of the built environment. ${ }^{101}$

In sum, the development and occupation of the Erber under the Drapers' Company suggests that the global enterprise of London's elite merchants was intimately connected to locally-embedded urban infrastructures. Since the late fifteenth century, many livery companies had built up significant city property portfolios by way of bequest and purchase. In ensuring the provision of buildings carefully attuned to the social and commercial needs of a variety of citizens, the 'great' livery companies worked to maintain and indeed amplify the overlap between membership of trading companies, livery companies, and, consequently, service in urban governance. The spatial substructures of global trade were however often unseen, rather like Fynes Moryson's experience of London's threatened courtyard houses in their recession from the streetfront, the spaces of profitable commercial enterprise could be embedded in multifunctional house-and-business complexes or constructed along narrow alleys. Microhistories of sites such as that of the Erber allow for the strong ties between globallyorientated mercantile exploits and high civic office to be unpicked, and reveal the often understudied ways in which the built environment adjusted to new scales of trade. ${ }^{102}$ In the densifying city, the Drapers' acquisition and tenancy of high-quality reputable courtyard buildings like the Erber indicates that such diverse properties could serve to bind elite merchants back into their local contexts. In particular, the Drapers' Company's affinity with the lucrative but politically volatile Spanish and Portuguese trade is seen in the occupation of the principal house. Meanwhile, like companies such as the Mercers and Merchant Taylors, the Drapers recognised the wider need to support its members' own building work and responded by ensuring a large storeyard with materials on hand to facilitate the making of new storage spaces in the city. Further, the Company endorsed proactive development of their properties by mercantile tenants of the lower sort, whose domestic exchanges could directly and indirectly support the activity of commercial globalization. The ways London changed in response to issues such as the logistical

\footnotetext{
${ }^{101}$ For an account of this in relation to the livery companies see: N. Zahedieh (The Capital and the Colonies: London and the Atlantic Economy, 1660-1700, (Cambridge, 2010), 55-136

${ }^{102}$ One exception, though for an earlier period is: A. Jordan Gschwend, K.J.P Lowe eds., The Global City: On the streets of Renaissance Lisbon (London, 2015)
} 
problems of carters and middling merchants were bound up with processes of rising global trade. In this way, the history of the Erber highlights the dialogic relationship between economic developments on global scales, and the social, political, and spatial circumstances of individual merchants within ever-more densely occupied early modern cities. 
Table 1 showing residents of the principal house of the Erber compiled from DCA, RA series:

\begin{tabular}{|c|c|c|c|c|c|}
\hline Name of Lessee & Trading Company & Civic Offices & Livery Company & Date of tenancy & Rent \\
\hline John Over & $\begin{array}{l}\text { Merchant Adventurer } \\
\text { (Governor) }\end{array}$ & - & Not known & c.1549-c.1555 & f22 10s \\
\hline $\begin{array}{l}\text { John Kendall (then } \\
\text { Widow Kendall) }\end{array}$ & Not known & - & Not known & c. $1555-1560$ & $f 2210 s$ \\
\hline Luis De Paz & N/A - Spanish denizen & $\mathrm{N} / \mathrm{A}$ & $\mathrm{N} / \mathrm{A}$ & $1560-1562$ & $f 2210 \mathrm{~s}$ \\
\hline Antonio de Guerras & N/A - Spanish denizen & $\mathrm{N} / \mathrm{A}$ & $\mathrm{N} / \mathrm{A}$ & $1562-1579$ & $f 263 s 4 d$ \\
\hline Thomas Pullison & $\begin{array}{l}\text { Merchant Adventurer, } \\
\text { Spanish Company, Eastland } \\
\text { Company (Director) }\end{array}$ & $\begin{array}{l}\text { Alderman (1573-1588), } \\
\text { Sheriff (1573-4), Lord Mayor } \\
(1584-5)\end{array}$ & $\begin{array}{l}\text { Draper (Warden, 1565-7, } \\
\text { Master, 1575) }\end{array}$ & $1579-1588$ & $f 263 s 4 d$ \\
\hline $\begin{array}{l}\text { Francis Drake } \\
\text { (b.1540 - d.1596) }\end{array}$ & $\mathrm{N} / \mathrm{A}$ & MP $(1572,1584,1593)$ & Draper & $1588-1593$ & $f 263 s 4 d$ \\
\hline
\end{tabular}




\begin{tabular}{|l|l|l|l|l|}
\hline Paul Banning & $\begin{array}{l}\text { East India Company } \\
\text { (Treasurer, 1600), Levant } \\
\text { Company, Spanish } \\
\text { Company (Director), Venice } \\
\text { Company }\end{array}$ & $\begin{array}{l}\text { Alderman (1593-1602), } \\
\text { Sheriff (1593-4) }\end{array}$ & Grocer & $1593-1612$ \\
\hline Edward Barkham & $\begin{array}{l}\text { East India Company, Levant } \\
\text { Company }\end{array}$ & $\begin{array}{l}\text { Alderman (1611-34), Sheriff } \\
(1611-12), \text { Lord Mayor } \\
(1621-2), \text { MP (1625-26) }\end{array}$ & $\begin{array}{l}\text { Leatherseller/Draper } \\
\text { (translated, 1621), Master } \\
\text { Leathersellers 1605-6, 1608-9; } \\
\text { Drapers 1622-3 }\end{array}$ & $\begin{array}{l}1612-1631 \\
\text { f26 3s 4d }\end{array}$ \\
\hline
\end{tabular}

